\title{
The Impact of the feelings of Economic powerlessness and alienation on self- employment intentions
}

\section{Peter P. Khaola}

\begin{abstract}
The purpose of this study was to examine the impact of the feelings of economic powerlessness \& alienation on self-employment intentions of young people. The data used in the study was collected through a survey of students at the National University of Lesotho, and the correlation and factor analyses, as well as standard multiple regressions were used to analyze the data. Two clear factor distinctions resulted from selfemployment intentions, namely, self-employment intentions regardless of unemployment, and self-employment intentions in response to unemployment. Similarly, the feelings of economic powerlessness and alienation separated into two factors, namely, economic powerlessness and 'business exploits'. The feelings of economic powerlessness impacted negatively on self-employment intentions, and the feeling that 'business exploits' impacted positively on self-employment intentions in response to unemployment. The results of the study suggest that young people who have high feelings of economic powerlessness would not normally plan to start their own businesses.
\end{abstract}

Key words: economic, powerlessness, alienation, job, unemployment

\section{Introduction}

The social, legal, political and economic contexts influence the willingness of people to start their own businesses. The factors in these external environments interact with attitudes to influence intentions (Bird, 1988, Boyd \& Vozikis, 1994).

The importance of economic issues on entrepreneurial behaviour is well known (Shane, 2003). It is especially known that people form attitudes and opinions on economic issues (Walstad, 1987). In turn, these economic attitudes, beliefs and opinions influence people's thoughts and actions.

Despite the well-known effects of economic values, attitudes and beliefs on certain work ethic beliefs related to self-employment, e.g. Protestant Work Ethic (PWE) beliefs (Furnham, 1987), the research on the relationship between the affective economic 
attitudes and self-employment intentions has not been given the attention it deserves. This is surprising because economic attitudes and opinions, as primary determinants of behavior, basically command the attention of policymakers (Walstad, 1987).

The current study was designed to fill that gap. Specifically, the study evaluates the impact of the related issues of the feelings of economic powerlessness and alienation on two separate forms of self-employment intentions, namely, self-employment intentions regardless of unemployment, and self-employment intentions if the young person does not get the job. It is argued that the two forms of intentions have clear factor distinctions and the feelings of economic powerlessness and alienation impact on them differently.

The paper contributes to existing literature in self-employment intentions in at least one distinct way. Much as powerlessness had been used before to predict people's voting preferences (e.g. Evans, 1993), to the best knowledge of the author, economic powerlessness is yet to be directly related to self-employment intentions, especially in a least developed country like Lesotho. Knowing what people think and how they feel is important because it gives policymakers and decision makers the possibility of predicting and influencing human behaviour (Walstad, 1987).

To better understand the results of this study and their discussion, section 2 after this introduction overviews the labour market in Lesotho, followed by the hypotheses development in section 3. Section 4 outlines the research method, and section 4 presents the results and their discussion. The conclusion is provided in the last section of the study.

\section{Overview of the Labour Market in Lesotho}

The Kingdom of Lesotho is a mountainous country of about 1.8 million people with a Constitutional Monarchy. It obtained its independence from Britain on October 4, 1966, and it is landlocked within the Republic of South Africa.

Labour statistics are rare in Lesotho, with only four Labour Force Surveys conducted since Independence in 1966. The latest surveys were conducted in 1997 and 1999. Unlike in other countries where the concept of 'labour force' is restricted to the working age of 15-64 years, in Lesotho 'labour force' includes all people aged 10 and above. In 1997, there were above 1.1 million people aged 10 and above, and in 1999 the figure grew to over 1.2 million people. The economically active people were 593189 and 849308 in 1997 and 1999 respectively.

Traditionally, Basotho men have relied on South African mines to provide much needed jobs, but since the 1980's, the number of jobs in the South African mining industry has been dwindling. For instance, there were about 128441 Basotho men working in South African mines in 1977 (Ketso, 1991:67), but due to retrenchments, Basotho workers remaining in South African mines were estimated at around 56000 at end of 2004 (Kapa, 2006:59)

According to Labour Force Surveys 1997 and 1999, the rate of open unemployment in Lesotho was estimated at $40.5 \%$ and $31.1 \%$ in 1997 and 1999 respectively. In terms of 
gender, both surveys indicate that more males than females were unemployed. This is not surprising because, unlike in other African countries, in Lesotho women are more educated than men, and according to Lesotho Labour Force Surveys, there is a clear correlation between educational attainment and employment. While the Lesotho economy generates about 6,000 new jobs per annum, it is estimated that on average, between 24,000 and 26,000 new job seekers enter the workforce every year, and about $19 \%$ of these come from tertiary institutions. Thus though unemployment is generally high for all age groups in Lesotho, it is relatively higher among young people.

Estimated at 50\% and $68.6 \%$ of labour force in 1997 and 1999 respectively, most people in Lesotho engage in subsistence farming. The increase in people who engage in subsistence farming somewhat explains the decrease in unemployment recorded between the two surveys. Next to subsistence farming, self-employment in Lesotho occurs mainly in the form of survivalist micro-enterprises within the informal sector of the economy.

\section{Self-Employment Intentions Models and Hypotheses}

Intentionality is the hallmark of the entrepreneurship process because individuals consciously take decisions to become entrepreneurs (Bird, 1988, Krueger, 1993, Krueger $\&$ Brazeal, 1994). The two classical entrepreneurial intentions models, namely, the theory of planned behavior (TPB), and its expectancy-driven counterpart, the Shapero's Entrepreneurial Event (Ajzen, 1991, Kruger, 1993), are extensively used in entrepreneurship research.

\section{The Theory of Planned Behaviour}

According to the Theory of Planned Behaviour, the behavioral intentions are the proximal determinant of behavior, and therefore intentions are the best predictors of behaviour (Ajzen, 1991, Krueger, 1993, Kolvereid, 1996). The three antecedents of intentions in this theory are the attitude towards behaviour, the subjective norm and the perceived behavioural control (See figure 1). The three antecedents are conceptualized respectively as the degree to which a person has a favourable appraisal of behaviour; the perceived social pressure to perform the behaviour; and the extent to which one perceives the behaviour to be under one's volitional control (Ajzen, 1988).

The Theory of Planned Behaviour has successfully been used to predict a wide range of human behaviours (Ajzen, 1991). In the context of entrepreneurship, the recent studies by Autio, Keeley, Klofsten, Parker and Hay (2001) and Kolvereid (1996) affirmed the robustness of the model. The studies established that all three antecedents were positively related to intentions to start a business venture or to be self-employed.

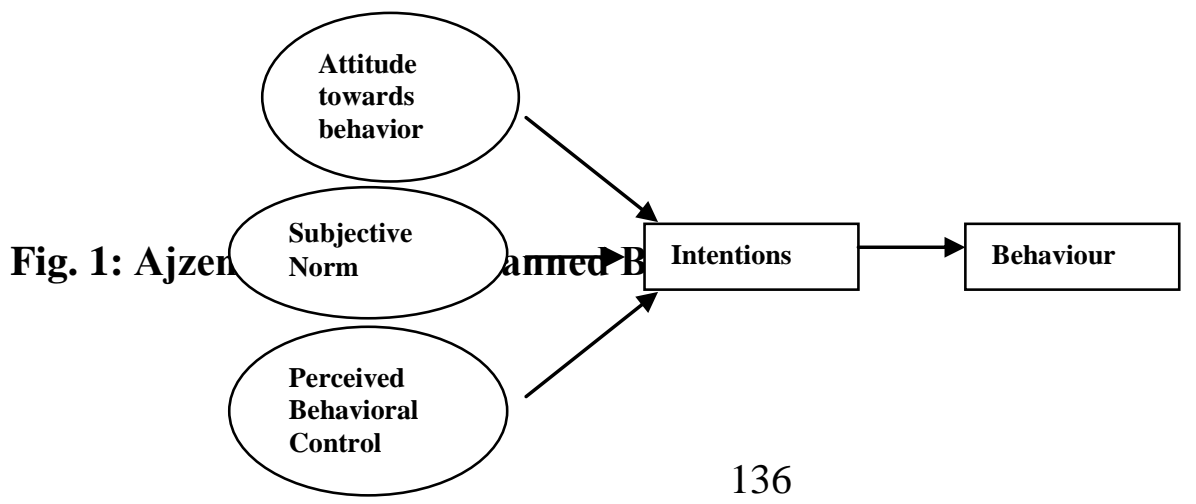




\section{Shapero's entrepreneurial event}

Predicated on the Theory of Planned Behavior, the Shapero's Entrepreneurial Event (Shapero, 1982) has been found to be particularly applicable in entrepreneurial studies (Davidson, 1995, Krueger, 1993, Kolvereid, 1996, 1997, Peterman \& Kennedy, 2003, Reitan, 1996). The antecedents of intention in Shapero's Entrepreneurial Event are perceived desirability, which is equivalent to attitudes and subjective norm in the theory of planned behaviour; perceived feasibility, which is equivalent to perceived behavioural control; and the propensity to act (Autio, Keeley, Klofsten, Parker \& Hay, 2001, Krueger, 1993) (See figure 2). In turn, feasibility and the perceived behavioural control are found to have features of Bandura's self-efficacy concept (Krueger, 1993).

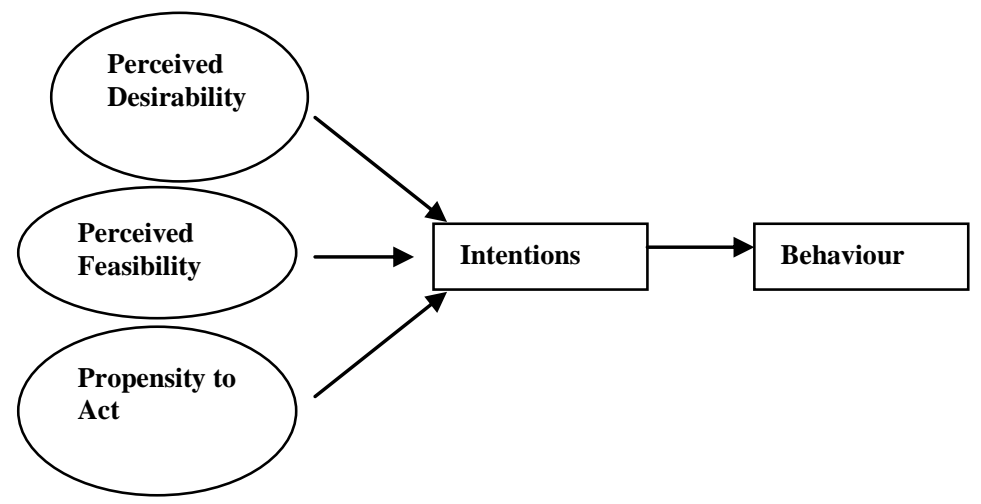

\section{Fig. 2: Shapero's Model of 'Entrepreneurial Event'}

Besides the individual differences and attitudes, the broader environmental factors have impact on self-employment intentions. The economic, legal and social situational factors interact with perceptions/attitudes to influence intentions (Bird, 1988; Boyd \& Vozikis, 1994). One of the situational factors that influence self-employment is unemployment. Kennedy, Drennan, Renfrow and Watson (2003) tested the role of two situational factors (displacement and family commitments) on Shapero's (1982) model, and found that where unemployment was likely, the subjective norm was a major influence on intentions. In a study of entrepreneurship behaviour of immigrant Russian Jews in Israel, Mesch and Czamanski (1997) found that the odds of business ownership were increased by the feelings that the immigrant could not find a job in his/her profession. It can therefore be argued that unemployment or threat of unemployment can have an effect on self-employment intentions. Given the high unemployment rate among young people (Rosas and Rossignotti, 2005), we expected that some participants in the present study would indicate willingness to start their businesses only if they were unemployed. In other words, we expected the clear factor distinctions between the intention to start own business regardless of unemployment status, and the willingness or intention to start own business in response to unemployment.

\section{Economic powerlessness and alienation}

McClelland (1961) was one of the first psychologists to relate the Protestant Work Ethic (PWE) to the capitalist mode of production (Furnham, 1987). He subsumed PWE (defined here as one's belief in the virtues of hard work, rationality and frugality) into a well-known dispositional variable, namely need for achievement (Furnham, 1987). He 
further argued that high need for achievement in the society was associated with growth in entrepreneurial behaviour.

Even though subsequent research produced equivocal findings with regard to the relationship between the need for achievement and entrepreneurship (Furnham, 1987; Gartner, 1988), prior research also indicated that concepts such as locus of control (Brockhaus, 1982; Lüthje \& Franke, 2003), perceived feasibility (Krueger, 1993), perceived behavioural control (Ajzen, 1991), self-esteem (Robinson, Stimson, Huefner \& Hunt, 1991), Protestant Work Ethic (Furnham, 1987), and self-efficacy (Boyd \& Vozikis, 1994) had a positive influence on entrepreneurial (self-employment) intentions.

Even though Furnham (1987) did not find a relationship between the need for achievement and the PWE, he found that economic beliefs were the third most important determinant of the PWE after locus of control and education. Since the feelings of economic powerlessness and alienation (personal efficacy) in this study express the young people's lack of control over the economic issues (O'Brien \& Ingels, 1987), and such powerlessness militates against the PWE and self-efficacy, it was expected that the students who expressed higher feelings of economic powerlessness and alienation (i.e. those with low personal efficacy) would express lower self-employment intentions. Thus:

Hypothesis 1 Controlling for the self-employment intentions in response to unemployment, the feelings of economic powerlessness and alienation are negatively related to self-employment intentions.

A lot has been written about the negative psychological effects of unemployment. For instance, Feather and O'Brien (1986) established that the self-worth, Protestant Work Ethic (PWE) and confidence of the unemployed youth diminish. Similarly, Rosas and Rossignotti (2005:156) indicate that 'lack of work is often accompanied by feelings of uselessness and worthlessness, which can lead to reduced self-esteem, depression and general unhappiness'. Given this scenario, it can be argued that unemployment results in feelings of economic powerlessness and alienation. Despite the influence of unemployment on the decision to exploit entrepreneurial opportunities (Shane, 2003), the psychological issues related to unemployment are yet to be related to intentions, especially self-employment intentions when unemployment was a threat. Since the youth who fear unemployment are likely to be individuals with external locus of control and low self-efficacy (those whose feelings of economic powerlessness and alienation are high), we expected that the students who expressed higher feelings of economic powerlessness and alienation would express high self-employment intentions only if unemployment was likely.

Hypothesis 2 Controlling for the self-employment intentions (regardless of unemployment), the feelings of economic powerlessness and alienation are positively related to self-employment intentions in response to unemployment. 


\section{Methodology \\ Sample and Procedures}

The paper is based on the data provided by a convenient sample of 523 undergraduate students of the National University of Lesotho taking at least one business course (about $71 \%$ of students registered for business courses). The subjects were asked to complete a self - administered questionnaire at their own pace. They were made aware that participation in the study was optional. A plea was made for submission of complete questionnaires only. Of the 523 questionnaires distributed, 504 were returned, a return rate of $96 \%$. Of the respondent sample, $50.6 \%$ were females, and $61.0 \%$ were single. The mean age of respondents was $21.9(\mathrm{SD}=5.3)$. 4 of the returned questionnaires were incomplete, and were therefore excluded from further analysis.

\section{Measures}

\section{Economic powerlessness and alienation}

Participants' feelings of economic powerlessness and alienation were measured with the powerlessness and alienation subscale of O'Brien and Ingels (1987) Economic Values Inventory. This subscale comprises seven items, and we rated them on a 5 point Likert type scale ranging from $1=$ strongly disagree, to $5=$ strongly agree. The items appear under factors 1 and 2 in the factor analysis solution in table 1. Factor 1 can be referred to as economic powerlessness, and following $\mathrm{Ng}$ and Allen (2005), we named the second factor 'business exploits'. A Cronbach's alpha for economic powerlessness (4 items) was 0.62 , and that of 'business exploits' (3 items) was 0.65. Cronbach's alpha of all 7 items was 0.65 .

\section{Self-employment intentions}

Two items were used to measure general self-employment intentions. One item, 'Estimate the likelihood that you will start your own business in the foreseeable future', was adapted from Davidson (1995), and was rated on a 5 point Likert type scale ranging from $1=$ not likely at all, to $5=$ very likely. The other item, 'Do you plan to be selfemployed in the foreseeable future after you leave NUL', was adapted from Lüthje and Franke (2003), and was rated on a 5 point Likert type scale ranging from $1=$ very improbable, to $5=$ very probable. Cronbanch's alpha of the two items was 0.57 .

Self-employment intentions if unemployed We developed two items to measure selfemployment intentions that could be influenced by unemployment. The two items were 'I only plan to set up my own business if I'm unemployed' and 'I expect to start up a business if there were no jobs available'. Cronbach's alpha of the two items was 0.50 . As shown in Table 1, the items were also factor analyzed to gauge whether or not they measure common dimensions.

Other Measures The survey included items inquiring about the participants' age, gender, programme of study, year of study, whether or not one was self-employed, and whether one's parents owned their full-time business enterprise. Prior research indicates that individual differences such as gender, age, and level of education, parental role models and prior experience have influence on entrepreneurial intentions (Crant, 1996; Krueger, 
1993). To test for the effects of the economic powerlessness and alienation on intentions, the effects of these demographic variables on intentions needed to be controlled.

\section{Results and Discussion}

The items used to measure the main variables were first factor analyzed (principal components, varimax rotation) to ensure that they measure similar dimensions. The factor loadings below 0.4 were suppressed. The solution of factor analysis is shown in table 1 .

Table 1: Results of Factor Analysis

\begin{tabular}{|c|c|c|c|c|}
\hline \multirow[t]{2}{*}{ Item } & \multicolumn{4}{|c|}{ Factor } \\
\hline & $\mathbf{1}$ & 2 & 3 & 4 \\
\hline 1. It's foolish to do more than you have to in a job & .741 & & & \\
\hline $\begin{array}{l}\text { 2. It is no use worrying about the economy, I can't do. } \\
\text { anything about it }\end{array}$ & .648 & & & \\
\hline $\begin{array}{l}\text { 3. The way our economic system is set up, nobody has a. } \\
\text { chance to get ahead anymore }\end{array}$ & .637 & & & \\
\hline 4. Getting ahead is mostly a matter of luck & .617 & & & \\
\hline $\begin{array}{l}\text { 5. Having the freedom to start my own business really } \\
\text { means having the freedom to take advantage of others }\end{array}$ & & .807 & & \\
\hline 6. Profit is a sign that someone is being taken advantage of & & .705 & & \\
\hline $\begin{array}{l}\text { 7. Being in business means taking unfair advantage of } \\
\text { others }\end{array}$ & & .662 & & \\
\hline $\begin{array}{l}\text { 8. Do you plan to be self-employed in the foreseeable } \\
\text { future after you leave NUL? }\end{array}$ & & & .826 & \\
\hline $\begin{array}{l}\text { 9. Estimate the likelihood that you will start your own } \\
\text { business in the foreseeable future }\end{array}$ & & & .780 & \\
\hline $\begin{array}{l}\text { 10. I expect to start up a business if there were no jobs } \\
\text { available }\end{array}$ & & & & .84 \\
\hline 11. I plan to set up my own business only if I 'm unemployed & & & & .70 \\
\hline
\end{tabular}

Component Analysis. Rotation Method: Varimax with Kaiser Normalization. Rotation converged in 6 iterations.

As shown in table 1, the results yielded 4 clear factors corresponding to economic powerlessness, 'business exploits', self-employment intentions, and self-employment intentions if one does not get employment. The factor loadings ranged from 0.617 to 0.847 .

As expected, the four items meant to measure self-employment intentions loaded on two separate factors (factors 3 and 4). Items 8 and 9 measure self-employment intentions regardless of unemployment, and items 10 and 11 measure self-employment intentions if the young person is unemployed. This result supports the fact that some young people planned to start their businesses only if they were unemployed, the fact that will be revisited below when we deal with the impact of economic powerlessness and the ideology that 'business exploits' on intentions. 
To have an overview of the inter-relationships between the main variables in the study, the descriptive statistics and inter-correlation coefficients of the variables were computed. The results are shown in Table 2 .

Table 2: The Descriptive Statistics and Inter-Correlation of Variables (Spearman's)

\begin{tabular}{|l|l|l|l|l|l|l|}
\hline Variables & Mean & SD & $\mathbf{1}$ & $\mathbf{2}$ & $\mathbf{3}$ & $\mathbf{4}$ \\
\hline 1. Intention & 4.08 & 0.80 & 1.000 & & & \\
\hline $\begin{array}{l}\text { 2. Intention if } \\
\text { (unemployed) }\end{array}$ & 2.62 & 0.96 & $-0.098^{*}$ & 1.000 & & \\
\hline $\begin{array}{l}\text { 3. Economic } \\
\text { powerlessness }\end{array}$ & 2.21 & 0.77 & $-0.209^{* *}$ & $0.130^{* *}$ & 1.000 & \\
\hline 4. 'Business exploits' & 2.22 & 0.89 & -0.018 & $0.206^{* *}$ & $0.214^{* *}$ & 1.000 \\
\hline
\end{tabular}

**Correlation is significant at 0.01 level (2-tailed)

${ }^{*}$ Correlation is significant at 0.05 level (2-tailed)

The inter-correlations in Table 2 indicate that self-employment intentions were negatively and significantly related to the feelings of economic powerlessness $(r=-0.209 p \leq 0.01)$. Curiously, self-employment intentions in response to unemployment were positively and significantly related to both economic powerlessness $(r=0.130 p \leq 0.01)$ and the ideology that 'business exploits' $(r=0.206 p \leq 0.01)$. These results suggest that young people with high feelings of economic powerlessness would not have intentions to start their businesses in the foreseeable future. However, when unemployment is high, young people with negative view about businesses and profit making could still be 'forced' into starting their own businesses.

To test for the individual effects of economic powerlessness and the feeling that 'business exploits' on self-employment intentions while controlling for the effects of other variables, two separate standard multiple regressions were run. General self-employment intentions and self-employment intentions if one was unemployed were respectively used as the dependent variables. In each case, the control variables (including each selfemployment intentions used as control) were entered in block 1 , and the dependent variables were entered in block 2 . The variance explained by control variables was not significant $\left(\mathrm{R}^{2}=0.014, \mathrm{~F}=0.685, \quad p \geq 0.05\right.$ and $\mathrm{R}^{2}=0.021, \mathrm{~F}=1.021, \quad p \geq 0.05$ respectively). Multicollinearity assessments were also conducted, and the results indicated that multicollinearity was not the problem in the two regression equations. The $\mathrm{t}$-values and Beta coefficients of simple multiple regressions are shown in Table 3. 
Table 3: Results of Standard Multiple Regression

\begin{tabular}{|l|l|l|l|l|}
\hline \multirow{2}{*}{ Variable } & \multicolumn{2}{|l|}{ Self-employment intentions } & \multicolumn{2}{l|}{$\begin{array}{l}\text { Self-employment intention } \\
\text { (if unemployed) }\end{array}$} \\
\cline { 2 - 5 } & & $\beta$ & $t$ & $\beta$ \\
\hline $\begin{array}{l}\text { Economic } \\
\text { powerlessness }\end{array}$ & $-3.835^{* *}$ & $-0.207^{* *}$ & 1.726 & 0.092 \\
\hline $\begin{array}{l}\text { 'Business } \\
\text { Exploits' }\end{array}$ & 0.428 & 0.023 & $3.383^{* *}$ & $0.177^{* *}$ \\
\hline
\end{tabular}

* Significant at $\rho \leq 0.05$

** Significant at $\rho \leq 0.01$

As predicted in hypothesis 1, Table 3 further supports that a high feeling of economic powerlessness is negatively associated to self-employment intentions ( $\beta=-0.207, p \leq 0.01)$. This finding is not surprising because prior studies indicated that locus of control (Brockhaus, 1982; Lüthje \& Franke, 2003), self-esteem (Robinson, Stimson, Huefner \& Hunt, 1991), and self-efficacy (Boyd \& Vozikis, 1994; Kriestiansen \& Indarti, 2004) had a positive influence on entrepreneurial (self-employment) intentions. Someone with higher feelings of economic powerlessness would likely be someone who feels their destiny is influenced by events beyond their control, and would likely have external locus of control, low self-esteem, and low self-efficacy. This perhaps explains why there is a negative association between the feelings of economic powerlessness and self-employment intentions. This implies that policymakers who are interested in increasing the self-employment intentions of young people can do so by restoring their confidence in the economy, and by improving their self-esteem and self-efficacy, e.g. through educational programmes.

Hypothesis 2 predicted that high feelings of economic powerlessness and alienation would be positively related to self-employment intentions if one were unemployed. The results indicate that the feelings of economic powerlessness produced a positive but not significant impact on self-employment intentions in response to unemployment ( $\beta=0.092 p \geq 0.05)$. However, a feeling that 'business exploits' was positively associated with self-employment intentions in response to unemployment ( $\beta=0.177, p \leq 0.01$ ). As suggested in prior studies, the decision to engage in selfemployment can be attributed to the 'life path change' of unemployment (Shapero, 1982:103). Thus unemployment or threat of unemployment in this case, can be a push factor into self-employment. The implication is that some young people can venture into self-employment regardless of their negative view of businesses and profit making, so long as they were unemployed.

Interestingly, there were significant gender mean differences pertaining to selfemployment intentions if one were unemployed, with females registering higher mean than males. While this statistic does not imply that business start up influenced by unemployment would be of lower quality, but it is also known that unemployment pushes more females than males into informal sector self-employment in Sub-Saharan Africa (Haan, 2001). Haan noted that many of these people 'do not have much choice, but are 
rather 'entrepreneur' by necessity rather than by conviction (p.34). The implication is that when unemployment is a threat, it can be difficult for governments and other policymakers to promote and fund convinced entrepreneurs, and therefore unemployment should by necessity be reduced to identify and nurture convicted entrepreneurs.

\section{Conclusion}

The aim of this study was to assess the influence of certain psychological youth feelings on self-employment intentions. The study evaluated the impact of the feelings of economic powerlessness and alienation on self-employment intentions. The results of factor analysis suggested clear factor distinctions between self-employment intentions regardless of unemployment, and self-employment intentions in response to unemployment. Similarly, the feelings of economic powerlessness and alienation separated into two factors, namely, economic powerlessness and the ideology that 'business exploits'. The feelings of economic powerlessness impacted negatively on selfemployment intentions, and the feeling that 'business exploits' impacted positively on self-employment intentions in response to unemployment. Thus the feelings of economic powerlessness can reduce the self-employment intentions, but if unemployment is likely, young people who have negative feelings about businesses and profit making could still start their own businesses.

Like all studies of each its nature, the current study had limitations. First, the convenient sample of students doing business courses was used; as such the results cannot be generalized beyond the sample. Second, as the respondents were all students, we could not get an objective reality of what the self-employment intentions would be under actual unemployment environment. The relationship between the feelings of economic powerlessness and alienation, and self-employment intentions could be best evaluated among the unemployed and underemployed youth. Third, the internal reliability (as measured by Cronbach's alpha) was not high enough for some constructs, mainly due to limited number of items used to measure those constructs. These limitations provide a platform for further research in this area.

\section{References}

Ajzen, I. 1991. The theory of planned behavior. Organisational Behaviour and Human Decision Processes, 50(2), 1 - 63

Ajzen, I. 1988. Attitudes, personality and behavior. Milton Keynes: Open University Autio, E., Keeley, R.H., Klofsten, M., Parker, G.C. \& Hay, M. 2001. Entrepreneurial intent among students in Scandinavia and in the USA. Enterprise and Innovation Management Studies, 2(2), 145 - 160

Bird, B. 1988. Implementing Entrepreneurial Ideas: The Case for Intentions. Academy of Management Reviews, 13(3), 442 - 453

Boyd, N.G., \& Vozikis, G.S. 1994. The influence of self-efficacy on the development of entrepreneurial intentions and actions. Entrepreneurship Theory and Practice, 63-77

Brockhaus, R. H. 1982. The psychology of the entrepreneur. in Kent, C. A, Sexton, D.L., Vesper, K.H. (eds.) The art and science of entrepreneurship, Englewood Cliffs, NJ, Prentice Hall, 39 - 56 
Crant, M. 1996. The Proactive Personality Scale as Predictor of Entrepreneurial Intentions, Journal of Small Business Management, 42-49

Davidson, P. (1995). Determinants of entrepreneurial intentions. Paper presented for the Rent IX Workshop, November 23 -24, Italy

Evans, G. 1993. Class, powerlessness and political polarization. European Journal of Social Psychology, 23, 495-511

Feather, N. T. And O'brien, G. E. 1986. A longitudinal study of the effects of employment and unemployment on school-leavers, Journal of Occupational Psychology, 59: 121-144

Furnham, A. 1987. Predicting protestant work ethic beliefs. European Journal of Personality, 1, 93-106

Gartner, W.B. 1988. Who is an entrepreneur? Is the wrong Question. American Journal of Small Business, 12 (Spring), 11 - 32

Gartner, W.B. 1990. What are we talking about when we talk about entrepreneurship? Journal of Business Venturing, 5: 15 - 28

Haan, H. C. 2001. Training for work in the informal sector: evidence form Eastern and Southern Africa. Occasional Paper of the International Training Center of the International Labour Organisation, Turin, Italy

Kolvereid, L. 1996. Prediction of employment status choice intentions, Entrepreneurship theory and practice, 21(1), 47-57

Kriestiansen, S. \& Indarti, N. 2004. Entrepreneurial Intention Among Indonesian and Norwegian Students, Journal of Enterprising Culture, 12(1): 55-78

Krueger, N. 1993. The impact of prior exposure on perceptions of new venture feasibility and desirability. Entrepreneurship Theory and Practice, 18(1), 5-21

Krueger, N. F. \& Brazeal, D. V. 1994. Entrepreneurial potential and potential entrepreneurs, Entrepreneurship: Theory and Practice, 18(31), 5-21

Labour Force Survey 1997. Employment policy formulation and labour market analysis. Ministry of Labour and Employment, and Bureau of Statistics, Lesotho

Labour Force Survey 1999. Employment policy formulation and labour market analysis. Ministry of Labour and Employment, and Bureau of Statistics, Lesotho

Lüthje, C. \& Franke, N. 2003. The making of an entrepreneur: testing a model of entrepreneurial intent among engineering students at MIT, Research and Management Development, 33(2), 135 - 147

Kennedy, J., Drennan, J., Renfrow, P. \& Watson, B. 2003. Situational Factors and Entrepreneurial Intentions, A paper presented at the $16^{\text {th }}$ Annual Conference of Small Enterprise Association of Australia and New Zealand, 28 September - 1 October 2003

Mesch, G. S. \& Czamanski, D. 1997. Occupational Closure and Immigrant Entrepreneurship: Russian Jews in Israel, Journal of Socio-Economics, 26(6), 597-611

Ng, S. H. \& Allen, M. W. 2005. Perception of Economic Distributive Justice: Exploring leading Theories, Social Behavior and Personality, 33(5): 435-454

O’brien, M.U. \& Ingels, S. J. 1987. Economic Values Inventory. Journal of Economic Education, 18(1), 7-17

Peterman, N.E. \& Kennedy, J. 2003. Enterprise Education: Influencing Students' Perceptions of Entrepreneurship, Entrepreneurship: Theory and Practice, 129-144 
Reitan, B. 1996. Entrepreneurial Intentions: a combined models approach. Paper presented at the $9^{\text {th }}$ Nordic Small Business Research Conference, Lillehammer, Norway, 29 - 31 May

Robinson, P. B., Stimson, D. V., Huefner, J. C. \& Hunt, H. K. 1991. An Attitude Approach to the prediction of entrepreneurship, Entrepreneurship Theory and Practice, Summer, 13-31

Rosas, G. \& Rossignotti, G. 2005. Starting the millennium right: Decent employment for young people, 144(2): 139-160

Shane, S. 2003. A General Theory of Entrepreneurship, The individual-opportunity nexus, Edward Elgar Publishing Ltd.

Shane, S. \& Venkataraman, S. 2000. The promise of entrepreneurship as a field of research, Academy of Management Review, 25(1): 217 - 226

Shapero, A. 1982. Social dimensions of entrepreneurship, in Kent, C. A, Sexton, D.L., Vesper, K.H. (eds.) The art and science of entrepreneurship, Englewood Cliffs, NJ, Prentice Hall, $39-56$

Walstad, W.B. 1987. Attitudes, Opinions, and Economic Understanding. Theory into Practice, XXVI (3), 223-230 